\title{
DDB-1 and CUL4-Associated Factor 7
}

National Cancer Institute

\section{Source}

National Cancer Institute. DDB-1 and CUL4-Associated Factor 7. NCI Thesaurus. Code C104183.

DDB1- and CUL4-associated factor 7 (342 aa, $239 \mathrm{kDa}$ ) is encoded by the human DCAF7 gene. This protein may play a role in regulation of transcription. 